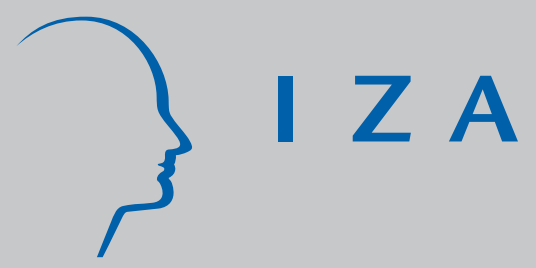

IZA DP No. 873

The Impact of Office Machinery and Computer Capital on the Demand for Heterogeneous Labour

Martin Falk

Bertrand M. Koebel

September 2003 


\title{
The Impact of Office Machinery and Computer Capital on the Demand for Heterogeneous Labour
}

\author{
Martin Falk \\ Austrian Institute of Economic Research (WIFO) \\ Bertrand M. Koebel \\ University of Magdeburg and IZA Bonn \\ Discussion Paper No. 873
September 2003
}

IZA

P.O. Box 7240

D-53072 Bonn

Germany

Tel.: +49-228-3894-0

Fax: +49-228-3894-210

Email: iza@iza.org

\begin{abstract}
This Discussion Paper is issued within the framework of IZA's research area The Future of Labor. Any opinions expressed here are those of the author(s) and not those of the institute. Research disseminated by IZA may include views on policy, but the institute itself takes no institutional policy positions.
\end{abstract}

The Institute for the Study of Labor (IZA) in Bonn is a local and virtual international research center and a place of communication between science, politics and business. IZA is an independent, nonprofit limited liability company (Gesellschaft mit beschränkter Haftung) supported by Deutsche Post World Net. The center is associated with the University of Bonn and offers a stimulating research environment through its research networks, research support, and visitors and doctoral programs. IZA engages in (i) original and internationally competitive research in all fields of labor economics, (ii) development of policy concepts, and (iii) dissemination of research results and concepts to the interested public. The current research program deals with (1) mobility and flexibility of labor, (2) internationalization of labor markets, (3) welfare state and labor market, (4) labor markets in transition countries, (5) the future of labor, (6) evaluation of labor market policies and projects and (7) general labor economics.

IZA Discussion Papers often represent preliminary work and are circulated to encourage discussion. Citation of such a paper should account for its provisional character. A revised version may be available on the IZA website (www.iza.org) or directly from the author. 
IZA Discussion Paper No. 873

September 2003

\section{ABSTRACT}

\section{The Impact of Office Machinery and Computer Capital on the Demand for Heterogeneous Labour ${ }^{*}$}

We study the impact of office and computing machinery (OCM) on the demands for workers with different educational levels. The empirical analysis relies on a system of demand equations that nests the translog, the generalised Leontief and the normalised quadratic specifications. Using panel data on 35 German industries, we find little evidence for a robust substitutability relationship between unskilled workers and OCM capital in manufacturing industries. In the non-manufacturing sector, however, we find some evidence for substitutability between OCM capital and unskilled workers.

JEL Classification: J23, O33

Keywords: skill-biased technological change, capital-skill complementarity

Corresponding author:

Bertrand M. Koebel

Otto-von-Guericke University

Postfach 4120

39016 Magdeburg

Tel.: +493916718 431

Fax: +493916711218

Email: koebel@ww.uni-magdeburg.de

\footnotetext{
* We would like to thank Bart Van Ark, Riccardo Lucchetti, Joachim Möller, Nanno Mulder, Walter Oberhofer, Alessandro Sterlacchini, Marcel Timmer, Kenneth Troske, and the seminar participants at Bonn (IZA), Innsbruck, Paris (Sorbonne) and Venice for helpful comments. We are also indebted to an anonymous referee for constructive comments and to Albert Müller for providing us with the computer investment data. Financial support from the European Community under the project 'Employment prospects in the knowledge economy' is gratefully acknowledged.
} 


\section{Introduction}

The diffusion of office and computing machinery (OCM) is often emphasized as one of the most important factors explaining the shift in labour demand towards skilled workers and away from unskilled workers (see among others, Autor, Katz and Krueger, 1998; Morrison-Paul and Siegel, 2001). During the 1980s and 1990s, the total stock of computing equipment grew rapidly as computer power exploded and prices of computers fell greatly. For the U.S., for instance, the total stock of quality adjusted computing equipment in constant prices grew with average growth rates between 20 and 30 percent per year (Jorgenson, 2001). German figures show similar tendencies.

This paper presents new empirical estimates of the impact of OCM capital on the demand for heterogeneous labour. Workers are classified according to whether they have a university degree, a certificate from the dual vocational system (including masters and technicians) and workers without any formal degree. The data consists of panel data on 35 two-digit manufacturing and non-manufacturing industries for Germany over the period 1978-1994. A four-equation input demand system, with three types of labour and total intermediate materials as variable factors as well as two types of capital, OCM capital and generic capital, as quasi-fixed inputs, is formulated and estimated. Our results suggest that computers increase the demand for high-skilled labour and to a lesser extent the demand for medium-skilled labour. This holds for both manufacturing and non-manufacturing industries. However, computer capital significantly decreases the demand for unskilled labour in non-manufacturing industries only. Overall, the results are somewhat consistent with the skill-biased technological change hypothesis. We also find that this finding is robust with respect to the choice of functional form and the definition of computer capital (quality adjusted or not).

There have been many empirical studies that focus directly on the relationship between the demand for labour at different skill levels and computerization (for a survey of the literature see Chennells and Van Reenen, 1999). Two empirical approaches have been used to estimate the relationship between the computerization and labour demand. The first approach relates the change in the employment share of skilled labour to the ratio of an industry's initial OCM capital (or OCM investment) to its total capital (or total investment) (see Berman, Bound and Griliches, 1994). Alternatively, the change in the employment share of skilled labour is related to the change in OCM investment ratio (see Autor, Katz and Krueger, 1998). The second approach employs a complete system of input demands, i.e. not only a relative labour demand equation (see Morrison-Paul and Siegel, 2001; Fitzenberger, 1999; Ruiz-Arranz, 2001).

Using a number of different data sets for the U.S. on three- and four-digit industry level, Autor, Katz and Krueger (1998) extend previous work in a number of ways. First, they use different measures of skills (four educational qualification groups as well as different occupational groups), different measures of information technology as well as a longer time period. Second, the authors also consider non-manufacturing industries. Using three-digit industry data, Autor et al. (1998) find that the change in computer use (measured as the annual change in the fraction of workers using a computer at work) is positively related to the change in the employment share of college graduates and, to a lesser extent, to workers with at least two years of college. In contrast, the change in computer use is negatively related to the change in the employment share of high school graduates. The relationship between the change in computer use and the change in the employment share 
of workers with less than high school is not significantly different from zero. Furthermore, the authors suggest that the shift towards college-educated workers and away from high school-educated workers was greatest in industries that experienced the greatest rise in computer use. Finally, the authors find that computer investment can account for at least 30 percent of the increase in the non-production worker wage bill for the period 1959 1989. Using similar approaches, Machin and Van Reenen (1998) find further support for the computer-skill complementarity. The authors use the proportion of workers using a computer at work as an index of computer use. Using two-digit manufacturing data for the U.S. and U.K., they find that the change in the cost share of non-production workers between 1986 and 1990 is positively related to the initial proportion of workers using a computer at work. Green, Felstead and Gallie (2000) investigate the impact of computer usage at work and other job features on the changing skills requirements of U.K. workers. The data are based on individual data of employed persons at three data points: 1986, 1992 and 1997. The authors find that the spread of computer usage is very strongly associated with the process of upskilling throughout the period. For France, Goux and Maurin (2000) find that the decline in the employment share of unskilled workers is mainly due to the slackness of domestic demand for those industries with the highest proportion of unskilled workers. In contrast, the spread of computers (measured amongst others as the percentage of workers using a computer on the job) has little effect on the labour demand for both skilled and unskilled workers.

Based on a complete system of input demands, Morrison-Paul and Siegel (2001) investigate the impact of high-tech office and information equipment, trade and outsourcing on heterogeneous labour demand. High-tech office and information equipment includes communications equipment, scientific and engineering instruments and photocopiers and related equipment in addition to office computing and accounting machinery. The authors estimate a seven equations input demand system derived from a generalised Leontief cost function with four educational qualification groups, energy and materials and an Euler equation for investment. Using U.S. two-digit manufacturing industry data, the authors find that the accumulation of high-tech capital explains 9 percent of the expanding employment of college graduates and 30 percent of the expanding employment of workers with some college experience for the period 1959-1989.

For Germany, Fitzenberger (1999) provides some evidence of the impact of computerization on labour demands for three types of labour (highly skilled, medium-skilled and unskilled workers) as well as materials. As neither OCM capital stock nor the price of OCM are available, Fitzenberger relies on the input coefficients (material inputs to total shipments) from the office machinery and computer industry and the electrical goods industry obtained from input-output tables as a proxy variable for OCM. Using two-digit industry data for non-manufacturing industries for the period 1975-1990, he finds little evidence for skill-biased technological change in non-manufacturing industries. The finding of no significant impact of intermediate OCM inputs could be due to the fact that the material inputs from the OCM industries do not seem to be correlated with OCM

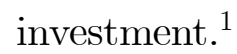

Whereas all these contributions rely on capital stocks or real investment that are not adjusted for changes in the quality, Krusell et al. (2000) construct capital stocks that

\footnotetext{
1 Across non-manfacturing industries, the correlation between the average annual rate of change in OCM investment and intermediate OCM inputs is -0.08 .
} 
are quality adjusted for investigating the impact of technological change on the ratio of skilled labour wages to unskilled labour wages. Using U.S. time series data, the authors find that capital-embodied technological change alone can account for most of the variations in the skill premium over the last 30 years. A key element of the Krusell et al. (2000) analysis is the use of quality-adjusted prices for a number of durable equipment categories such as office and computing equipment including peripheral equipment and accounting machinery (OCAM), communication equipment, general industrial equipment and transportation equipment. There has been a strong decline in the relative price of equipment (ratio of the price index for capital equipment and the price index for consumption of non-durables and services) of about 7 percent per year and an associated strong increase in the stock of equipment. The results imply that technological change is driven by the cheapening of equipment relative to structures and that technological change leads to a change in the composition of the capital stock. Ruiz-Arranz (2001) extends the work of Krusell et al. (2000) by distinguishing between the effects of information and communication capital (ICT capital) and non-ICT capital on the demand for skilled and unskilled workers. ${ }^{2}$ She finds that ICT capital is complementary to skilled labour and very substitutable to unskilled labour.

The paper proceeds as follows. Section 2 outlines the specification of both the generalised Box-Cox cost function, the normalised quadratic, the Leontief cost function and the translog cost function as well as the derived factor demands, while section 3 describes and summarizes the data. Section 4 presents the estimates of input demand elasticities as well as a decomposition analysis of the employment changes into output, capital and price effects. Section 5 concludes.

\section{The empirical model}

Most earlier work on the demand for heterogenous labour employs either the translog or the generalised Leontief cost function. The results of these studies, however, are difficult to compare because the functional forms are different. Therefore, following Koebel, Falk and Laisney (2003), we rely on an extension of Berndt and Khaled's (1979) Box-Cox cost function, in a way that nests three usual functional forms: (i) the translog cost function, (ii) the quadratic cost function and (iii) the generalised Leontief cost function. The generalised Box-Cox type of cost function can be written as:

$$
c\left(p_{n t}, z_{n t}, \alpha_{n}, \gamma\right)=\left\{\begin{array}{cc}
p_{n t}^{\prime} \bar{x}_{n}\left(\gamma_{2} C\left(P_{n t}, Z_{n t} ; \alpha_{n}\right)+1\right)^{1 / \gamma_{2}} & \text { for } \quad \gamma_{2} \neq 0 \\
p_{n t}^{\prime} \bar{x}_{n} \exp \left(C\left(P_{n t}, Z_{n t} ; \alpha_{n}\right)\right) & \text { for } \quad \gamma_{2}=0
\end{array}\right.
$$

with

$$
C\left(P_{n t}, Z_{n t} ; \alpha_{n}\right)=\alpha_{0 n}+A_{p n} P_{n t}+A_{z} Z_{n t}+\frac{1}{2} P_{n t}^{\prime} A_{p p} P_{n t}+P_{n t}^{\prime} A_{p z} Z_{n t}+\frac{1}{2} Z_{n t}^{\prime} A_{z z} Z_{n t},
$$

where the subscripts $t$ and $n$ denote time and industry, respectively. The technological parameters to be estimated are gathered in the vector $\left(\alpha_{n}^{\prime}, \gamma_{1}, \gamma_{2}\right)^{\prime}$, where $\alpha_{n}$ entails all free parameters of $\alpha_{0 n}, A_{p n}, A_{z}, A_{p p}, A_{p z}$ and $A_{z z}$. Notice that subscript $n$ characterizes parameters which are industry-specific. The vector of variable inputs is defined as $x_{n t}=$

\footnotetext{
2 ICT capital includes office, computing and accounting machinery, communications equipment, instruments, photocopy and related equipment.
} 
$\left(x_{h n t}, x_{s n t}, x_{u n t}, x_{m n t}\right)^{\prime}$ and the corresponding price vector as $p_{n t}=\left(p_{h n t}, p_{\text {snt }}, p_{\text {unt }}, p_{m n t}\right)^{\prime}$, where the labour input $x_{h n t}$ denotes the number of workers with a university degree, $x_{\text {snt }}$ denotes workers with a certificate from the dual vocational system plus masters and technicians, $x_{u n t}$ low-skilled or unskilled workers and $x_{m n t}$ total materials. Labour is measured in total workers (full-time equivalents). The net capital stock (excluding OCM capital), $z_{k n t}$, and the OCM capital stock, $z_{\text {ont }}$, are quasi-fixed factors. ${ }^{3}$ Other explanatory variables entering the cost function are the level of production, $z_{y n t}$, and a time trend $t$. The two types of capital, output and time are regrouped in a vector $z_{n t}=\left(z_{k n t}, z_{\text {ont }}, z_{y n t}, t\right)^{\prime}$. Total variable costs are measured as the sum of labour costs and total materials: $c_{n t}=p_{n t}^{\prime} x_{n t}$. Some restrictions are placed on the parameters in order for the Hessian of the cost function to be symmetric in $P$ and $Z$ for the number of parameters to be parsimonious:

$$
\iota_{4}^{\prime} A_{p n}=1, A_{p p}=A_{p p}^{\prime}, A_{z z}=A_{z z}^{\prime}, \iota_{4}^{\prime} A_{p p}=0, \iota_{4}^{\prime} A_{p z}=0,
$$

where $\iota_{4}$ denotes a $(4 \times 1)$-vector of ones. The components $P_{j}$ and $Z_{j}$ of the vector $P$ and $Z$ are Box-Cox transformations of the corresponding variables $p_{j n t}$ and $z_{j n t}$ :

$$
\begin{aligned}
& Z_{j n t}= \begin{cases}\frac{z_{j n t}^{\gamma_{1}}-1}{\gamma_{1}} \text { for } \gamma_{1} \neq 0 & , j=k, o, y, \\
\ln z_{j n t} & \text { for } \gamma_{1}=0\end{cases} \\
& P_{j n t}=\left\{\begin{array}{ll}
\frac{\left(p_{j n t} / p_{n t}^{\prime} \theta_{n}\right)^{\gamma_{1}}-1}{\gamma_{1}} & \text { for } \gamma_{1} \neq 0 \\
\ln p_{j n t} & \text { for } \gamma_{1}=0
\end{array}, j=h, s, u, m .\right.
\end{aligned}
$$

The two parameters $\gamma_{1}$ and $\gamma_{2}$ capture the way that variables $z_{j n t}$ and $p_{j n t}$ are transformed by the power function. Note that in (4), the transformation is not applied to the time trend but only to generic capital, OCM capital and output. The $(4 \times 1)$ vector $\theta_{n}$ is equal to $\bar{x}_{n} / \bar{p}_{n}^{\prime} \bar{x}_{n}$, where $\bar{p}_{n}$ and $\bar{x}_{n}$ are fixed levels of prices and quantities, so that $p_{n t}^{\prime} \theta_{n}$ corresponds to a Laspeyres price index for total variable costs. Note that for $\gamma_{2} \neq 0$, both functions $P_{j}$ and $C$ are homogeneous of degree zero in prices, so that the multiplicative term $p_{n t}^{\prime} \bar{x}_{n}$ appearing in expression (1) ensures that the cost function is linearly homogeneous in prices. In the Translog case, it is the restrictions (3) that guarantee degree one price homogeneity.

The translog (TL), the normalised quadratic as well as the generalised Leontief functional form are nested within the above specification. From the definition of $P_{j}$ and restrictions (3) it is direct to see that when $\gamma_{1} \rightarrow 0$ and $\gamma_{2} \rightarrow 0$ the cost function (1) yields:

$$
\begin{aligned}
\ln c_{T L}\left(p_{n t}, z_{n t} ; \beta_{n}\right)= & \beta_{0 n}+\left(\ln p_{n t}\right)^{\prime} B_{p n}+\left(\ln z_{n t}\right)^{\prime} B_{z}+\frac{1}{2}\left(\ln p_{n t}\right)^{\prime} B_{p p}\left(\ln p_{n t}\right) \\
& +\left(\ln p_{n t}\right)^{\prime} B_{p z}\left(\ln z_{n t}\right)+\frac{1}{2}\left(\ln z_{n t}\right)^{\prime} B_{z z}\left(\ln z_{n t}\right) .
\end{aligned}
$$

The relationship between the matrices $A$ and $B$ (and the parameters $\alpha_{n}$ and $\beta_{n}$ ) is described in Koebel, Falk and Laisney (2003).

\footnotetext{
3 An alternative possibility would be to model variable costs with computer capital as a variable input and general capital as a quasi-fixed input.
} 
Similarly, the normalised quadratic (NQ) cost function is obtained as special case of a generalised Box-Cox cost function for $\gamma_{1}=1$ and $\gamma_{2}=1$ :

$$
\begin{aligned}
c_{N Q}\left(p_{n t}, z_{n t} ; \beta_{n}\right)= & p_{n t}^{\prime} B_{p n}+\frac{1}{2} \frac{p_{n t}^{\prime} B_{p p} p_{n t}}{\theta_{n}^{\prime} p_{n t}}+p_{n t}^{\prime} B_{p z} z_{n t} \\
& +\theta_{n}^{\prime} p_{n t}\left(\beta_{0 n}+z_{n t}^{\prime} B_{z}+\frac{1}{2} z_{n t}^{\prime} B_{z z} z_{n t}\right),
\end{aligned}
$$

For $\gamma_{1}=0.5$ and $\gamma_{2}=1$, the generalised Leontief (GL) specification is obtained:

$$
\begin{aligned}
c_{G L}\left(p_{n t}, z_{n t} ; \beta_{n}\right)= & \sqrt{\theta_{n}^{\prime} p_{n t}}\left(p_{n t}^{1 / 2}\right)^{\prime} B_{p n}+\frac{1}{2}\left(p_{n t}^{1 / 2}\right)^{\prime} B_{p p} p_{n t}^{1 / 2}+\sqrt{\theta_{n}^{\prime} p_{n t}}\left(p_{n t}^{1 / 2}\right)^{\prime} B_{p z} z_{n t}^{1 / 2} \\
& +\theta_{n}^{\prime} p_{n t}\left(\beta_{0 n}+\left(z_{n t}^{1 / 2}\right)^{\prime} B_{z}+\frac{1}{2}\left(z_{n t}^{1 / 2}\right)^{\prime} B_{z z} z_{n t}^{1 / 2}\right)
\end{aligned}
$$

Further nested functional forms as well as more details on the derivations are provided by Koebel, Falk and Laisney (2003).

For all the different functional forms of the cost function, a system of optimal input demands $x^{*}\left(p_{n t}, z_{n t} ; \alpha_{n}, \gamma\right)$ is derived by the application of Shepards' lemma. The regression of the four-input demand system is specified in term of input/output coefficients:

$$
x_{n t} / z_{y n t}=x^{*}\left(p_{n t}, z_{n t}, \alpha_{n}, \gamma\right) / z_{y n t}+e_{n t},
$$

where $e_{n t}$ denotes a residual vector that has zero mean and a constant variance matrix and that is uncorrelated with the explanatory variables. The quadratic and generalised Leontief factor demand system can be estimated by linear SUR with fixed effects. The translog factor demand system as well as the Box-Cox factor demand system have to be estimated by non-linear SUR. For a given industry $n$, there are $36+2$ free parameters $\alpha_{n}$ and $\gamma$ in the Box-Cox case, two more parameters than with the nested specifications. Note that the inclusion of industry dummies may not be sufficient to allow for heterogeneity across industries.

The elasticities of the demand for labour at different skill levels with respect to the quantity of OCM capital, $z_{o}$, and non-OCM capital, $z_{k}$ :

$$
\epsilon\left(x_{j}^{*}, z_{i}\right)=\frac{\partial x_{j}^{*}}{\partial z_{i}} \frac{z_{i}}{x_{j}^{*}},
$$

where $j=h, s, u$, respectively and $i=k, o$, respectively. The main hypothesis to be tested is that unskilled labour is a substitute for OCM capital but highly skilled workers are complementary to OCM capital. A positive sign indicates a complementary relationship. A weaker form of computer capital skill complementarity states that unskilled workers also benefit from the increase in the OCM capital stock; however, the effect is much lower than the impact of OCM capital on skilled or highly skilled workers.

\section{Data and descriptive statistics}

The data sample used consists of panel data on 35 West German industries for the period 1978 - 1994. The basic data source are the National Accounts. From 58 industries, we selected a subset of 54 industries, excluding the public sector as well as agriculture which are subsidized and may not be cost minimizing. 
Data sources for wages and employment by different educational levels are described in Falk and Koebel (2001). Wages are measured as average annual salaries (plus fringe benefits and non-wage labour costs) paid to full-time workers and are calculated from a one percent random sample of the German social security accounts.

A drawback of this database is that earnings for university graduates are topcoded. In general, earnings of university graduates can be calculated from the wage and salary statistics of the German statistical office. This database, however, is limited in coverage, in particular for some non-manufacturing industries. For these industries, we assume that the ratio of earnings between workers with vocational degree and university graduates is similar to the corresponding ratio in the trade, transport and financial intermediation sector.

Another drawback of this database is that self-employed workers, civil servants and short-time employment are not covered by the social security statistics, leading to underestimate the number of workers by more than $20 \%$ in some sectors. We choose to exclude these sectors from the sample, which is reduced to 35 industries (24 manufacturing and 11 non-manufacturing).

Using these individual data sets, we calculate, for each sector, the number of workers and the wage for three types of educational levels: workers with a university degree, workers with a vocational degree, and those without formal degree. Some descriptive statistics on the evolution of labour input and wages are given in Table 2. It can be seen that the growth rates of the number of employed workers of different educational levels are quite different. In constrast, the evolution of the labour costs are quite similar across across educational levels. It is noteworthy that growth rates of any inputs are always greater in the non-manufacturing sectors than in manufacturing industries. This is partly due to greater average output growth in non-manufacturing (with $2.7 \%$ yearly).

Investment in office machinery and computers (OCM) is obtained from the capital flow tables provided by the IFO institute (see Faust et al., 1999). These series are fully compatible with the German national accounts and are available for the western part of Germany for the period 1970-1994 and including East Germany from 1995 onward. The rental use of OCM equipment is excluded from the definition. Office and computing machinery (OCM) as defined in the German national accounts consists of computers and associated peripherals (such as mainframes, personal computers, direct access storage devices, printers, terminals, tape drives, storage devices), office machinery equipment (such as electronic calculating machines, cash registers, accounting machines, typewriters and other mechanical writing equipment) and photocopiers and related equipment. In the U.S. national accounts the corresponding asset category is office, computing and accounting machinery (OCAM) which does not include photocopiers. ${ }^{4}$

In order to obtain OCM investment in constant prices, nominal investment must be deflated by an investment deflator for OCM equipment. Unfortunately, hedonic price deflators for OCM investment or the output of the OCM industry do not exist for Germany (Deutsche Bundesbank, 2000). We experiment three choices of the deflator: two of them

\footnotetext{
4 Usually, the definition of information and communications technologies would also include the two other asset categories, namely communications equipment and software (development, maintenance or related services) but should exclude office machinery (see Jorgenson, 2001). In a broad sense, high-tech capital can be defined as "information processing equipment", consisting of office, computing and accounting machinery, communications equipment, scientific and engineering instruments, photocopiers and related equipment (see Morrison, 1997, Morrison-Paul and Siegel, 2001).
} 
are quality adjusted and one is not. Quality adjusted price indices are available for France and the U.S. Van Ark (2001) suggests that the U.S. deflator for OCM investment may lead to an exaggeration of the price decline, since computer hardware production in the U.S. mainly consists of PCs and semiconductors, whereas computer production in the EU is more dominated by the production of peripheral equipment. In order to overcome this problem, we mainly rely on the French quality-adjusted price index of OCM equipment (including photocopiers) to deflate nominal OCM investment. ${ }^{5}$ The estimates in Tables 3 to 5 and Table 7 are obtained for OCM capital calculated from the French deflator.

For comparison, we also employ the U.S. price index for OCAM equipment, which is calculated by the Bureau of Economic Analysis's (BEA). Price indices for OCAM equipment are taken from the NIPA Table 7.8 published by the BEA. Starting from 1985, BEA has used hedonic price indices for computer equipment to deflate its national accounts output and investment data (BEA, 2001, Whelan, 2002). There, separate price indices are available for (i) computers and peripheral equipment, (ii) office and accounting equipment and (iii) photocopiers and related equipment. The NIPA table provides estimates for the quality-adjusted price index of computers and peripheral equipment for the period 1966-2000. The measured price decline is 16.3 percent per year for computer and peripheral equipment for the period 1970-1999. In contrast, the prices of office and accounting equipment and photocopiers and related equipment increased by 1.2 and 2.5 percent over the period 1970 to 1999 , respectively.

As we are interested in obtaining an aggregate price index for OCAM investment, we aggregate the three different price indices using a Törnquist price index. The change in the Törnquist price index, $\Delta p_{o t} / p_{o t-1}$ can be written as:

$$
\frac{\Delta p_{o t}}{p_{o, t-1}}=\sum_{i=1}^{3} \frac{\Delta q_{i t}}{q_{i, t-1}} \frac{1}{2}\left(s_{i, t}+s_{i, t-1}\right)
$$

where $\Delta q_{i t} / q_{i, t-1}$ is the annual growth rate of the three product groups in year $t$ and $s_{i, t}$ is the nominal investment share of the three product groups in year $t .{ }^{6}$ As the aggregate price index $p_{o, t}$ is normalised to one in 1991, the whole price serie can be calculated from $\Delta p_{o t} / p_{o, t-1}$. Three different U.S. price indices are constructed this way: (i) price index of OCAM equipment excluding photocopiers and related equipment, adjusted for exchange rate movements, (ii) price index of OCAM plus photocopiers and related equipment adjusted for exchange rate movements, (iii) price index of OCAM plus photocopiers and related equipment adjusted for exchange rate movements using Purchasing Power Parity (PPP) between the German mark and the U.S. dollar (information provided by the OECD).

Table 1 summarizes the evolution of the different deflators. Both the U.S. and the French price index of OCM equipment rapidly declined and this decline accelerated in the second half of the 1990s. The U.S. price index falls between 7.2 and 9.6 percent per year between the period 1970 to 1991 depending whether or not photocopiers and related equipment are included (see Table 1). Note that the decline in the U.S. price index of OCAM equipment is consistent with the corresponding price index presented in Jorgenson

\footnotetext{
5 We would like to thank Nanno Mulder for providing us with the French price index of OCM equipment.

$6 \quad$ The three product groups are: (i) computers and peripheral equipment, (ii) office and accounting equipment and (iii) photocopiers and related equipment.
} 
Table 1: Average annual changes in different price indices of OCM equipment

\begin{tabular}{lrr}
\hline \hline investment deflators, all adjusted for exchange rate changes & '70-'91 & '91-'99 \\
\hline U.S. deflator of OCAM investment (BEA) & -9.6 & -16.3 \\
U.S. deflator of OCAM + photocopiers (BEA) & -7.2 & -13.2 \\
U.S. deflator of OCAM + photocopiers (adj. using PPP) & -6.0 & -14.9 \\
French deflator of OCM investment (INSEE) & -8.4 & -10.0 \\
German producer prices of the OCM industry & -1.2 & -4.4 \\
German implicit deflator of OCM investment & 0.7 & -0.8 \\
\hline \hline
\end{tabular}

Notes: Average annual percentage rates of growth. The U.S. price indices are constructed using the Törnquist formula. OCAM is defined as office, computing and accounting machinery. Source: U.S. price indices: BEA, Table 5.8, 7.8.; Statistical Office Germany; INSEE; PPP rates: OECD; own calculations.

and Stiroh (1995) who find a yearly average decline of about 10.2 percent over the period 1970-1991. In all cases, the price decline accelerated over the period 1991 to 1999. The choice of the conversion method appears to be relatively unimportant as the decline in the price index based on PPP is very close to the price index based on current exchange rates. The French price index of OCM equipment converted in German marks fell by 10 percent per year for the period 1991 to 1999 (see Table 1). Figure 1 in the appendix shows the movements of the resulting deflators expressed in German marks for the period 1970 to 1991. Figure 2 in appendix depicts the progression of the corresponding deflators for the period 1991 to 1999 .

Looking at two indices that are not quality adjusted, we observe a low rate of price change (two last lines of Table 1). The German implicit deflator of office machinery and computer equipment slightly increased for the period 1970 to 1985, remained stable over the period 1986 to 1994 and then began to slightly decline in 1995. The official producer price index for the office machinery and computers industry, reported the $6^{\text {th }}$ row of Table 1 declined by an average 1.2 percent per year over the period 1970-1991 and about 4.4 percent per year for the period 1991 to 1999 (see also Schreyer, 2002).

Using the price index for OCM capital, we deflate nominal investment to obtain instment in constant price, and to construct OCM capital stock from the perpetual inventory method. Here, we rely on the U.S. depreciation rate reported by Fraumeni (1997), which is about 0.2729 for the years before 1978 and 0.3199 from 1978 onwards. These rates are high and they are higher than the implicit depreciation rates based on the German national accounts. The initial OCM capital stock in 1970 is assumed to be equal to the OCM investment in constant prices in 1970 divided by the depreciation rate. General capital is obtained by subtraction of OCM investment from total investment (both in nominal prices) and then applying the perpetual inventory method on deflated investment flows. Figure 3 in appendix shows the evolution of the OCM capital stock in total manufacturing using different deflators for OCM investment. The average growth rates of the OCM capital stock calculated from the French and U.S. deflator ranges between 20.4 and 21.9 percent per year. Since the investment deflator is falling quickly, much of the measured real growth rate of the OCM capital stock is actually attributable to the deflator. The general conclusion is that growth in the OCM capital stock is not sensitive to the choice of the quality adjusted deflator. For quality unadjusted deflators, however, the growth rate 
of the OCM capital stock is much lower: with the implicit German deflator for instance, OCM capital grows only about 10 percent in average per year.

Table 2: Annual changes in input quantities and factor prices

\begin{tabular}{|c|c|c|c|c|c|c|c|c|}
\hline & \multicolumn{4}{|c|}{ manufacturing } & \multicolumn{4}{|c|}{ non-manufacturing } \\
\hline & ean & s.d. & $\min$ & $\max$ & mean & s.d. & $\min$ & $\max$ \\
\hline & \multicolumn{8}{|c|}{ \% change in input quantities and output } \\
\hline university gra & 3.7 & 4.6 & -10.9 & 30.7 & 4.9 & 3.6 & -5.5 & 15.0 \\
\hline vocatio & 0.2 & 3.3 & -12.7 & 7.8 & 1.8 & 2.6 & -6.9 & 8.3 \\
\hline no forn & -3.5 & 5.3 & -19.2 & 21.6 & -1.6 & 4.3 & -14.7 & 13.4 \\
\hline tota & 1.8 & 6.0 & -22.9 & 19.1 & 3.0 & 5.4 & -18.8 & 33.4 \\
\hline & 0.4 & 2.9 & -7.2 & 8.7 & 2.7 & 2.8 & -5.9 & 11.4 \\
\hline $\mathrm{OCl}$ & 21.9 & 18.0 & -17.3 & 91.4 & 23.8 & 17.9 & -15.6 & 84.1 \\
\hline \multirow[t]{2}{*}{ gross output, $z_{y}$} & 1.2 & 5.4 & -23.1 & 16.0 & 2.7 & 4.1 & -11.2 & 12.9 \\
\hline & \multicolumn{8}{|c|}{$\%$ change in factor prices } \\
\hline & 4.5 & 2.2 & -8.4 & 12.4 & 4.4 & 2.3 & -3.9 & 11.3 \\
\hline & 4.2 & 2.4 & -7.8 & 15.8 & 4.5 & 2.7 & -4.5 & 14.0 \\
\hline no $f$ & 4.5 & 2.5 & -6.7 & 15.8 & 4.6 & 2.8 & -7.9 & 14.1 \\
\hline total materials, $p_{m}$ & 2.2 & 4.7 & -22.6 & 26.7 & 2.9 & 3.9 & -10.4 & 17.8 \\
\hline
\end{tabular}

Notes: Annual percentage rates of growth for 24 and 11 industries over the period 1979-1994. For each variables, there are 384 observations in manufacturing and 176 in non manufacturing. Source: Statistical Office Germany, IFO capital flow tables, Federal Labor Office, INSEE, own calculations.

Table 2 presents summary statistics on the annual change in quantities and factor prices for the 24 manufacturing and 11 non-manufacturing industries over the period 1978-1994. The OCM capital stock in constant prices grew in average at a faster rate than all other inputs. Over the period 1978-1994, the (French price index based quality adjusted) OCM capital stock increased by 22 percent per year in manufacturing and 24 percent per year in non-manufacturing industries.

\section{Empirical results}

For a given industry, the complete Box-Cox model (9) consists of 36 free parameters (including 4 industry specific parameters) plus two Box-Cox parameters $\gamma_{1}$ and $\gamma_{2}$. In order to allow for more heterogeneity across industries we estimate separate factor demand systems for (i) durable goods industries (12 industries), (ii) non-durable goods industries (12 industries) and non-manufacturing sector (11 industries). This gives a total of 82 parameters for sample split (i) and (ii) and 78 parameters for sample split (iii), that have to be estimated on the basis of $12 \times 17 \times 4=816$ and $11 \times 17 \times 4=748$ observations respectively.

For convenience, we will comply with the unfortunate practice of speaking about the level of skill though we actually only observe educational levels. So we use the adjectives high-skilled, skilled and unskilled for denoting respectively university graduates, workers with a vocational degree and those with no formal education.

Table 3 contains the estimates of the Box-Cox (BC) parameters $\gamma_{1}$ and $\gamma_{2}$ for the separate estimation samples. Note that both $\gamma_{1}$ and $\gamma_{2}$ range between 0 and 1 indicating 
that both the generalised Leontief (GL) and Translog (TL) functional form are more appropriate in explaining the data than the normalised Quadratic (NQ) functional form. Wald and likelihood ratio tests for the hypotheses that $\gamma_{1}=\gamma_{2}=0$, that $\gamma_{1}=\gamma_{2}=1$ and that $\gamma_{1}=1 / 2, \gamma_{2}=1$, lead to rejection of the underlying functional form in all cases. The values of the log-likelihood, reported in Table 3, confirm these findings. Pooling durable and nondurable industries, just as pooling manufacturing and non-manufacturing sectors, is also rejected by the data. ${ }^{7}$ The Likelihood ratio test values obtained for different null hypotheses are above the 5 percent critical values, and this for any functional forms of the cost function.

Table 3: Estimates of the Box-Cox parameters and specification tests

\begin{tabular}{|c|c|c|c|c|c|c|}
\hline & \multicolumn{2}{|c|}{ Estimates $^{(a)}$} & \multicolumn{4}{|c|}{ Log-likelihood value } \\
\hline Sample & $\gamma_{1}$ & $\gamma_{2}$ & $\mathrm{BC}$ & TL & $\mathrm{NQ}$ & GL \\
\hline non-durables (i) & $\begin{array}{c}0.51 \\
(13.1)\end{array}$ & $\begin{array}{l}0.37 \\
(12.4)\end{array}$ & 3212.7 & 3110.9 & 3137.5 & 3098.3 \\
\hline durables (ii) & $\begin{array}{c}0.38 \\
(8.7)\end{array}$ & $\begin{array}{c}0.19 \\
(5.4)\end{array}$ & 3056.1 & 3032.7 & 2955.8 & 2880.5 \\
\hline total manufacturing (i)\&(ii) & $\begin{array}{c}0.45 \\
(14.6)\end{array}$ & $\begin{array}{l}0.26 \\
(10.7)\end{array}$ & 6091.2 & 5971.7 & 5840.6 & 5746.6 \\
\hline non-manufacturing (iii) & $\begin{array}{c}0.58 \\
(13.1)\end{array}$ & $\begin{array}{l}0.38 \\
(14.9)\end{array}$ & 2515.9 & 2459.9 & 2383.6 & 2336.2 \\
\hline pooled (i), (ii) and (iii) & $\begin{array}{c}0.18 \\
(8.5)\end{array}$ & $\begin{array}{c}0.08 \\
(6.5)\end{array}$ & 8144.5 & 8107.4 & 7055.9 & 7098.8 \\
\hline
\end{tabular}

(a) t-values in parentheses.

We report the elasticities obtained from estimating the factor demand system in Tables 4 and 5. Table 4 provides the elasticities of factor demand for the manufacturing sector based on split sample estimates distinguishing between durables and non-durables. Table 5 provides the elasticities for the non-manufacturing sector.

Elasticities are calculated at the midpoint data in 1986. Because the results for different industries are too voluminous to be discussed in detail, we report only the median elasticity (over industries) as well as the t-statistic of the corresponding median elasticity. For the same reason, we only present the elasticities obtained from the generalised Box-Cox functional form. Own-price and cross-price elasticities of factor demand are given in the upper panel of Tables 4 and 5. A positive sign outside the diagonal element indicates that the two corresponding inputs are substitutes. The elasticities of the different educational qualification groups with respect to generic capital as well as OCM capital are given in row five and six of Table 4 and Table 5. A positive sign indicates a complementary relationship, whereas the negative sign indicates that the two inputs are substitutes. Output elasticities and the impact of time are provided in row seven and eight of Table 4 and Table 5.

For manufacturing industries, the own price elasticities are significantly negative, except for the own-wage elasticity of highly skilled workers. We find that unskilled and high-skilled workers tend to be complementary. All other flexible inputs tend to be substitutes. The results from the lower panel of Table 4 indicate that an increase in the

\footnotetext{
$7 \quad$ A likelihood ratio test for the null of identical parameters across industries rejects the pooled model: $2 \times$ $(3212.7+3056.1-6091.2)=355.2$, where $6,091.2$ is the log-likelihood value of the pooled model and the first two log-likelihood values correspond to those of the two split sample regressions. Under the null hypothesis, this test statistic is chi-squared distributed with 34 degrees of freedom. The five percent critical value is 48.32 .
} 
Table 4: Elasticities of factor demand obtained from the BC cost function based on split sample, manufacturing

\begin{tabular}{lccccc}
\hline \hline$\epsilon(j ; i)$ & $x_{h}^{*}$ & $x_{s}^{*}$ & $x_{u}^{*}$ & $x_{m}^{*}$ \\
\hline \multicolumn{5}{c}{ price elasticities } \\
\hline$p_{h}$ & -0.37 & 0.01 & -0.06 & 0.00 \\
& $(-1.5)$ & $(0.3)$ & $(-2.9)$ & $(2.1)$ \\
$p_{s}$ & 0.02 & -0.23 & 0.01 & 0.05 \\
& $(0.3)$ & $(-8.9)$ & $(0.1)$ & $(3.6)$ \\
$p_{u}$ & -0.18 & 0.01 & -0.21 & 0.03 \\
& $(-3.1)$ & $(0.2)$ & $(-2.8)$ & $(2.8)$ \\
$p_{m}$ & 0.20 & 0.19 & 0.23 & -0.10 \\
& $(0.7)$ & $(5.6)$ & $(3.9)$ & $(-7.0)$ \\
\hline \multicolumn{5}{c}{ scale elasticities } \\
\hline$z_{k}$ & 0.90 & 0.28 & 0.08 & 0.14 \\
& $(9.4)$ & $(8.2)$ & $(1.1)$ & $(4.5)$ \\
$z_{o}$ & 0.12 & 0.01 & -0.00 & 0.01 \\
& $(7.2)$ & $(1.6)$ & $(-0.1)$ & $(1.1)$ \\
$z_{y}$ & 0.26 & 0.39 & 0.54 & 0.87 \\
$t$ & $(0.6)$ & $(9.5)$ & $(8.0)$ & $(30.0)$ \\
& 0.001 & 0.002 & -0.040 & 0.001 \\
& $(0.1)$ & $(0.8)$ & $(-10.7)$ & $(0.3)$ \\
\hline \hline
\end{tabular}

Notes: The median value of the elasticities at 1986 data is reported. t-values of the medain elasticities in parentheses.

Table 5: Elasticities of factor demand obtained from the BC cost function, non-manufacturing

\begin{tabular}{|c|c|c|c|c|}
\hline$\epsilon(j ; i)$ & $x_{h}^{*}$ & $x_{s}^{*}$ & $x_{u}^{*}$ & $x_{m}^{*}$ \\
\hline \multicolumn{5}{|c|}{ price elasticities } \\
\hline$p_{h}$ & $\begin{array}{c}-0.91 \\
(-1.8)\end{array}$ & $\begin{array}{c}-0.14 \\
(-2.4)\end{array}$ & $\begin{array}{c}0.58 \\
(3.0)\end{array}$ & $\begin{array}{c}0.03 \\
(4.6)\end{array}$ \\
\hline$p_{s}$ & $\begin{array}{c}-1.12 \\
(-2.3)\end{array}$ & $\begin{array}{c}-0.39 \\
(-4.2)\end{array}$ & $\begin{array}{c}0.50 \\
(2.3)\end{array}$ & $\begin{array}{l}0.19 \\
(6.3)\end{array}$ \\
\hline$p_{u}$ & $\begin{array}{l}1.56 \\
(3.0)\end{array}$ & $\begin{array}{l}0.14 \\
(1.6)\end{array}$ & $\begin{array}{l}-1.28 \\
(-3.2)\end{array}$ & $\begin{array}{l}0.02 \\
(2.4)\end{array}$ \\
\hline$p_{m}$ & $\begin{array}{l}0.42 \\
(2.7)\end{array}$ & $\begin{array}{l}0.34 \\
(4.2)\end{array}$ & $\begin{array}{l}0.13 \\
(1.9)\end{array}$ & $\begin{array}{c}-0.24 \\
(-7.2)\end{array}$ \\
\hline \multicolumn{5}{|c|}{ scale elasticities } \\
\hline$z_{k}$ & $\begin{array}{l}1.01 \\
(7.5)\end{array}$ & $\begin{array}{l}0.42 \\
(5.7)\end{array}$ & $\begin{array}{c}-0.19 \\
(-2.2)\end{array}$ & $\begin{array}{l}0.00 \\
(0.0)\end{array}$ \\
\hline$z_{o}$ & $\begin{array}{l}0.11 \\
(4.4)\end{array}$ & $\begin{array}{l}0.05 \\
(3.3)\end{array}$ & $\begin{array}{l}-0.11 \\
(-4.6)\end{array}$ & $\begin{array}{c}-0.01 \\
(-1.1)\end{array}$ \\
\hline$z_{y}$ & $\begin{array}{c}-0.44 \\
(-2.7)\end{array}$ & $\begin{array}{c}-0.02 \\
(-0.2)\end{array}$ & $\begin{array}{l}1.10 \\
(9.4)\end{array}$ & $\begin{array}{l}1.04 \\
(10.0)\end{array}$ \\
\hline$t$ & $\begin{array}{c}0.020 \\
(3.1)\end{array}$ & $\begin{array}{c}0.006 \\
(1.7)\end{array}$ & $\begin{array}{c}-0.014 \\
(-3.8)\end{array}$ & $\begin{array}{c}0.001 \\
(0.1)\end{array}$ \\
\hline
\end{tabular}


OCM capital stock has only a sizable and significant impact on the demand for highskilled workers. Based on split sample estimates, the median elasticity of OCM capital stock with respect to highly skilled workers is about 0.12 and highly significant. The elasticities of the OCM capital stock with respect to medium-skilled workers and unskilled workers are very close to zero and insignificant. The median elasticity of generic capital with respect to university graduates is about 0.90 and highly significant. The impact of generic capital on both medium-skilled workers and unskilled workers is positive and significant at the five percent level but somewhat lower than the impact of capital on university graduates $\left(\varepsilon\left(x_{s}^{*}, z_{k}\right)=0.28\right.$ and $\left.\varepsilon\left(x_{u}^{*}, z_{k}\right)=0.08\right)$. This indicates that the impact of generic capital (non-OCM capital) on employment is increasingly positive with the skill level $\left(\varepsilon\left(x_{h}^{*}, z_{k}\right)>\varepsilon\left(x_{s}^{*}, z_{k}\right)>\varepsilon\left(x_{u}^{*}, z_{k}\right)\right)$. This is consistent with a weaker form of the capital-skill complementarity hypothesis. Furthermore, output elasticities for mediumskilled workers and unskilled workers are positive and significant with a higher output elasticity for unskilled workers than for medium-skilled workers. The demand for highly skilled workers, however, seems to be rather independent of changes in output.

For non-manufacturing industries (Table 5), we find that input demands are more reactive to their own-price than it is the case in manufacturing. The results in the lower panel of Table 5, show that OCM capital has a significantly positive impact on the employment of skilled and high-skilled workers. However, OCM capital decreases the demand for unskilled workers. Similarly, an increase in generic capital increases the demand for high skilled and skilled labour and reduces the demand for unskilled workers. The elasticity of the employment of unskilled workers with respect to generic capital is -0.19 compared to the elasticity of generic capital with respect to highly skilled workers and medium-skilled workers of about 1.01 and 0.42 , respectively. This is consistent with the hypothesis of capital-skill complementarity, which states that unskilled workers and capital are substitutes while skilled workers and capital tend to be complements.

\subsection{Sensitivity of the OCM elasticities with respect to the deflator of OCM investment}

The choice of the French deflator for computing the quality adjusted OCM capital stock is somewhat arbitrary and in this subsection, we consider two other possible choices for deflating investment and constructing the capital stock $z_{\text {ont }}$ : the U.S quality adjusted and the German deflators that is not adjusted for changing quality (see the $2^{\text {nd }}$ and $5^{\text {th }}$ row of Table 1 and Figures 1 to 3 in the appendix for comparison).

Table 6: Elasticities of employment with respect to OCM capital based on different deflators of OCM investment (obtained from the Box-Cox)

\begin{tabular}{|c|c|c|c|c|}
\hline & \multicolumn{2}{|c|}{ manufacturing } & \multicolumn{2}{|c|}{ non-manufacturing } \\
\hline$\overline{\mathrm{OCM}}$ & $\overline{\mathrm{US}}$ & German & $\overline{\mathrm{US}}$ & German \\
\hline elasticities & deflator & deflator & deflator & deflator \\
\hline$\epsilon\left(x_{h}^{*}, z_{o}\right)$ & $\begin{array}{l}0.12 \\
(6.7)\end{array}$ & $\begin{array}{c}0.13 \\
(3.8)\end{array}$ & $\begin{array}{c}0.13 \\
(5.4)\end{array}$ & $\begin{array}{c}0.13 \\
(3.6)\end{array}$ \\
\hline$\epsilon\left(x_{s}^{*}, z_{o}\right)$ & $\begin{array}{l}0.02 \\
(2.3)\end{array}$ & $\begin{array}{c}0.03 \\
(2.0)\end{array}$ & $\begin{array}{c}0.07 \\
(4.7)\end{array}$ & $\begin{array}{c}0.06 \\
(1.6)\end{array}$ \\
\hline$\epsilon\left(x_{u}^{*}, z_{o}\right)$ & $\underset{(0.7)}{0.02}$ & $\begin{array}{c}0.03 \\
(1.7)\end{array}$ & $\begin{array}{c}-0.08 \\
(-3.7)\end{array}$ & $\begin{array}{c}-0.18 \\
(-2.0)\end{array}$ \\
\hline
\end{tabular}


Table 6 presents the elasticities of the different skill levels with respect to OCM capital based on different deflators for OCM investment for the manufacturing sector. A comparison between the three deflators (French, German and U.S.) shows that OCM elasticities are quite similar, although the evolution of the deflators and capital stock are very different. Despite these similar elasticities, the most striking feature of Table 6 is that the impact of OCM capital accumulation on employment is somewhat sensitive with respect to the choice of the deflator of OCM investment. Indeed, the overall impact of OCM capital accumulation on input demand $x_{j}^{*}$ is approximately given by $\epsilon\left(x_{j}^{*}, z_{o t}\right) \cdot \Delta z_{o t} / z_{o t}$ which depends upon the growth rate of the capital stock (adjusted or not) and this implies different overall impacts though the elasticities are rather similar.

Based on the French deflator, the elasticity of highly skilled workers with respect to the OCM capital stock is between 0.11 and 0.12 (see Tables 4, 5 and 6). As the growth rate of the OCM capital stock based on the U.S. price index for OCAM plus photocopiers and related equipment (converted in local currency) is about 22.4 percent per year, this implies that between 62 and 74 percent of the expanding employment of highly skilled workers can be attributed by the increase in the OCM capital stock. Based on the U.S. deflator, the elasticity of highly skilled workers with respect to OCM capital is 0.12 and the increase in the OCM capital stock 20.4, which leads to similar conclusion as with the French deflator.

However, the impact of OCM capital stock on the employment change of university graduates is considerably lower when the German deflator is used to construct OCM capital stocks. Given an increase in the OCM capital stock based on the German deflator of about 10 percent per year, only between 34 and 37 percent of the observed expanding employment for university graduates can be attributed to the increase in the OCM capital stock. As the German deflator does not include any changes in the quality of OCM investment, it understates the price decline of OCM investment. This leads to an underestimation of the impact of OCM capital accumulation on labour demands. Similar conclusions can be drawn for the other labour inputs.

\subsection{Sources of employment change by skill level}

Given the estimated values of the elasticities of input demand, one can calculate how much of the observed change in employment can be attributed to the effects of prices, output, two types of capital and time. After a total differentiation of the labour demand equations and the following transformation into growth rates, the predicted percentage change of employment of the different educational qualification levels can be written as:

$$
\frac{\Delta x_{g n t}}{x_{g n t}} \simeq \sum_{j=h, s, u, m} \varepsilon\left(x_{g}, p_{j}\right) \frac{\Delta p_{j n t}}{p_{j n t}}+\sum_{i=k, o, y} \varepsilon\left(x_{g}, z_{i}\right) \frac{\Delta z_{i n t}}{z_{i n t}}+\varepsilon\left(x_{g}, t\right),
$$

where $\Delta x_{g n t} / x_{\text {gnt }}$ denotes the actual employment growth rate of the three types of labour $(g=h, s, u)$ which should be close to the observed employment growth rate. The first term on the right-hand side of the equality captures the price effects calculated as the product of price changes and the estimated price elasticities; the second term on the right-hand side measures the impact of the two types of capital and the impact of output. The results of the decomposition analysis appear in Table 7. Both the observed and the predicted employment change are given in column two and three of Table 7 . In general, the predicted changes are relatively close to the observed ones. Columns 4 to 8 contain 
the different sources of employment change.

Table 7: Sources of employment change of university graduates and unskilled workers

\begin{tabular}{|c|c|c|c|c|c|c|c|}
\hline \multirow{3}{*}{$\begin{array}{l}\text { Types } \\
\text { of worker }\end{array}$} & \multirow{2}{*}{\multicolumn{2}{|c|}{$\begin{array}{c}\text { Employment } \\
\text { change per year }\end{array}$}} & \multicolumn{5}{|c|}{ Sources in percent of actual change } \\
\hline & & & \multirow[b]{2}{*}{ price } & \multirow{2}{*}{$\begin{array}{l}\text { generic } \\
\text { capital }\end{array}$} & \multirow{2}{*}{$\begin{array}{l}\text { OCM } \\
\text { capital }\end{array}$} & \multirow[b]{2}{*}{ output } & \multirow[b]{2}{*}{ time } \\
\hline & observed & predicted & & & & & \\
\hline & \multicolumn{7}{|c|}{ manufacturing, BC, split sample } \\
\hline$x_{h}$ & 3.1 & 0.9 & -0.7 & -0.2 & 1.8 & -0.1 & 0.1 \\
\hline$x_{u}$ & -4.0 & -4.2 & -0.4 & -0.0 & -0.0 & 0.4 & -4.0 \\
\hline & \multicolumn{7}{|c|}{ non-manufacturing, $\mathrm{BC}$} \\
\hline$x_{h}$ & 4.5 & 4.3 & -0.4 & 2.3 & 1.8 & -1.4 & 2.0 \\
\hline$x_{u}$ & -2.5 & -2.6 & -0.7 & -0.8 & -2.2 & 2.7 & -1.6 \\
\hline
\end{tabular}

For manufacturing industries, the main cause of the increase in the demand of highly skilled workers is the growing OCM capital stock. Here, 58 percent of the employment change of university graduates can be explained by computerization during the period 1978-1994. The demand for unskilled labour is unaffected by computerization. Using U.S. manufacturing data for the period 1959-1989, Morrison-Paul and Siegel (2001) find that the accumulation of high-tech capital has accounted for 9 percent of the expanding employment for college graduates for the period 1959-1989. In manufacturing, output plays a minor role in explaining the employment change of highly skilled and unskilled workers. This is mainly because output growth is very low in these industries. Similarly, wage and substitution effects between different types of labour and between labour and material inputs are relatively limited too. Though we now have two types of capital inputs, Solows' residual is still very important as it implies an autonomous decrease in the demand for unskilled labour by about 4 percent a year.

In non-manufacturing industries, 40 percent of the observed employment change of highly skilled workers can be attributed to the increase in the OCM capital stock. In contrast, OCM capital decreased the demand of unskilled workers by -2.2 percent in average per year, which explains the bulk of the shift away from unskilled labour in nonmanufacturing. The impact of generic capital on the demand for heterogeneous labour is more important than it is the case in manufacturing. Here, about 50 percent of the increase in employment of university graduates can be explained by the increase in generic capital.

\section{Conclusions}

The purpose of this paper has been to investigate the relationship between the increased growth of the OCM capital stock and the labour demand for different educational qualification groups. A static factor demand models assuming a generalised Box-Cox, a generalised Leontief, a normalised quadratic and a translog functional form of the cost function are employed. This paper develops new estimates of the office machinery and computer (OCM) capital stock. French and U.S. price indices (adjusted for exchange rate changes) are used as deflators for OCM investment. Estimates using French and U.S. deflators for OCM investment imply that the growth in the German OCM capital stock based on the 
official OCM investment deflators is significantly underestimated by about 10 percentage points per year. We also examine the sensitivity of the key elasticities with respect to the deflator for OCM investment.

The empirical results indicate that the accumulation of the OCM capital stock is the major factor contributing to the shift in labour demand towards highly skilled workers. Accumulation of OCM capital accounts for between 60 and 71 percent of the expanding employment of university graduates in manufacturing industries between the period 19781994. In non-manufacturing industries, both OCM capital and generic capital accounted for nearly all of the change in the employment of university graduates. Contrary to expectation, we do not find a robust substitutability pattern between OCM capital and unskilled workers. Finally we find that effects of the OCM capital stock are robust with respect to the choice of the deflator for OCM investment.

\section{References}

Autor, D. H., L. F. Katz and A. B. Krueger, 1998, Computing Inequality: Have Computers Changed the Labour Market, Quarterly Journal of Economics 113, 11691213.

Berman, E., J. Bound and Z. Griliches, 1994, Changes in the Demand for Skilled Labor within U.S. Manufacturing: Evidence from the Annual Survey of Manufactures, Quarterly Journal of Economics 109, 367-397.

Berndt, E. R. and M. S. Khaled, 1979, Parametric Productivity Measurement and Choice among Flexible Functional Forms, Journal of Political Economy 87, 1220-1245.

Bureau of Economic Analysis, 2001, A Guide to the NIPA's, National Income and Product Accounts of the United States, 1929-97.

Chennells, L. and J. Van Reenen, 1999, Has Technology Hurt Less Skilled Workers? An Econometric Survey of the Effects of Technical Change on the Structure of Pay and Jobs, IFS Working Paper 99-27, Institute for Fiscal Studies, London.

Deutsche Bundesbank, 2000, Problems of International Comparisons of Growth caused by Dissimilar Methods of Deflation - with IT Equipment in Germany and the United States as a Case Point, Monthly Report, August 2000, p. 8.

Falk, M. and B. M. Koebel, 2001, A Dynamic Heterogeneous Labor Demand Model for German Manufacturing, Applied Economics 33, 339-348.

Faust, K., M. Hummel, A. Müller, C. Saul, H. Schedl und M. Wilhelm, 1999, Der Beitrag des IuK-Sektors zur Verbesserung der Innovations- und Wettbewerbsfähigkeit der inländischen Produktion und Beschäftigung. Strukturberichterstattung 1996-1998: Neue Informations- und Kommunikationstechnologien, Tertiarisierung und Globalisierung - Herausforderungen für den Strukturwandel, IFO Studien zur Strukturforschung 28/I, München 1999.

Fitzenberger, B., 1999, Wages and Employment across Skill Groups: An Analysis for West Germany, ZEW Economic Studies 6, Physica. 
Fraumeni B., 1997, The Measurement of Depreciation in the U.S. National Income and Product, Survey of Current Business July 7-41.

Goux G. and E. Maurin, 2000, The Decline in Demand for Unskilled Labor: An Empirical Analysis Method and its Application to France, Review of Economics and Statistics 82, 596-607.

Green, F., A. Felstead and D. Gallie, 2000, Computers Are Even More Important Than You Thought: An Analysis of the Changing Skill-Intensity of Jobs, Centre for Economic Performance Discussion Paper, No 439.

Jorgenson, D. W., 2001, Information Technology and the U.S. Economy, American Economic Review 91, 1-32.

Jorgenson, D. W. and K. Stiroh, 1995, Computers and Growth, Economics of Innovation and New Technology 3, 295-316.

Koebel B. M., M. Falk and F. Laisney, 2003, Imposing and Testing Curvature Conditions on a Box-Cox Cost Function, Journal of Business and Economic Statistics 21, 319-335.

Krusell P., L. E. Ohanian, J.-V. Rios-Rull and G. L. Violante, 2000, Capital-Skill Complementarity and Inequality: A Macroeconomic Analysis, Econometrica 68, 10291053.

Machin S. and J. Van Reenen, 1998, Technology and Changes in Skill Structure: Evidence from Seven OECD Countries, Quarterly Journal of Economics 113, 1215-44.

Moch, D., 2001, Price Indices for Information and Communication Technology Industries: An Application to the German PC Market, ZEW Discussion paper, 01-20.

Morrison, C. J., 1997, Assessing the Productivity of Information Technology Equipment in U.S. Manufacturing Industries, Review of Economics and Statistics 79, 471481.

Morrison-Paul, C. J., and D. Siegel, 2001, The Impacts of Technology, Trade, and Outsourcing on Employment and Labor Composition, Scandinavian Journal of Economics 103, 241-264.

Ruiz-Arranz, M., 2001, Wage Inequality and Information Technology, mimeo, Harvard University.

Schreyer, P., 2002, Computer Price Indices and International Growth and Productivity Comparisons, Review of Income and Wealth 48, 15-32.

Van Ark, B., 2001, The Renewal of the Old Economy: an International Comparative Perspective, OECD STI Working paper, No. 5.

Whelan, K., 2002, A Guide to U.S. Chain Aggregated NIPA Data, Review of Income and Wealth 48, 217-234. 
Figure 1: Deflators for OCM investment, 1970-1990

$1991=1$

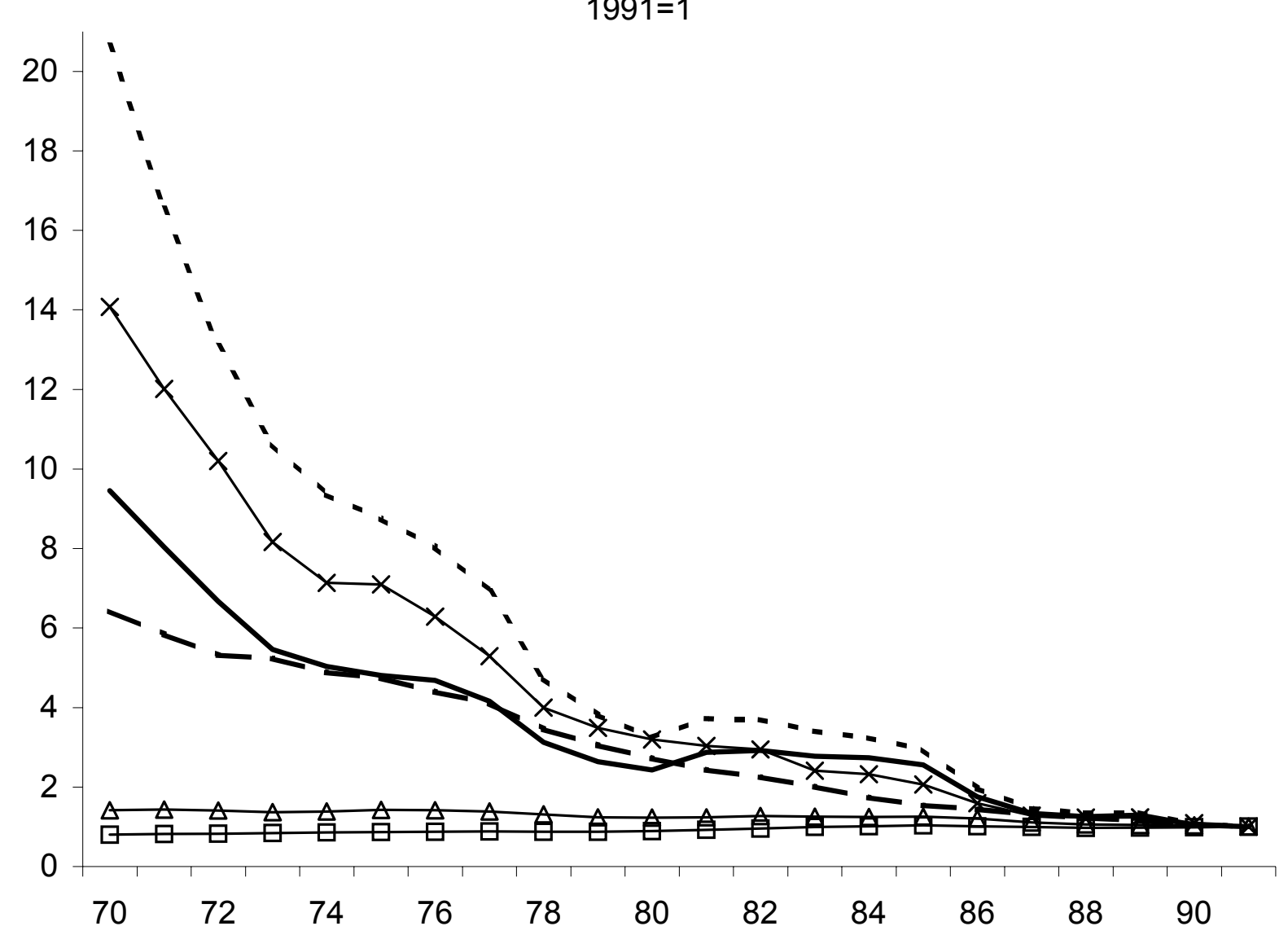

- - - U.S. deflator for OCAM investment, converted into DM using current DM/US\$ exchange rate

$\longrightarrow$ French deflator for OCM investment, converted into DM using current DM/FF exchange rate

-U.S. deflator for OCAM investment plus photocopy and related equipment, converted into DM using current DM/US\$ exchange rate

- -U.S deflator for OCAM investment plus photocopy and related equipment, converted into DM using PPP between DM and US\$

$\triangle$ German OCM industry producer price index (DM)

——German deflator for OCM investment (DM)

Notes: OCM denotes office machinery and computers, OCAM denotes office computing (incl. peripheral equipment) and accounting equipment. PPP denotes Purchasing Power Parities for GDP.

Sources: U.S Bureau of Economic Analysis, NIPA Table 5.9, 5.8 and 7.8, INSEE, Statistical Office Germany, own calculations. 
Figure 2: Deflators for OCM investment, 1991-1999

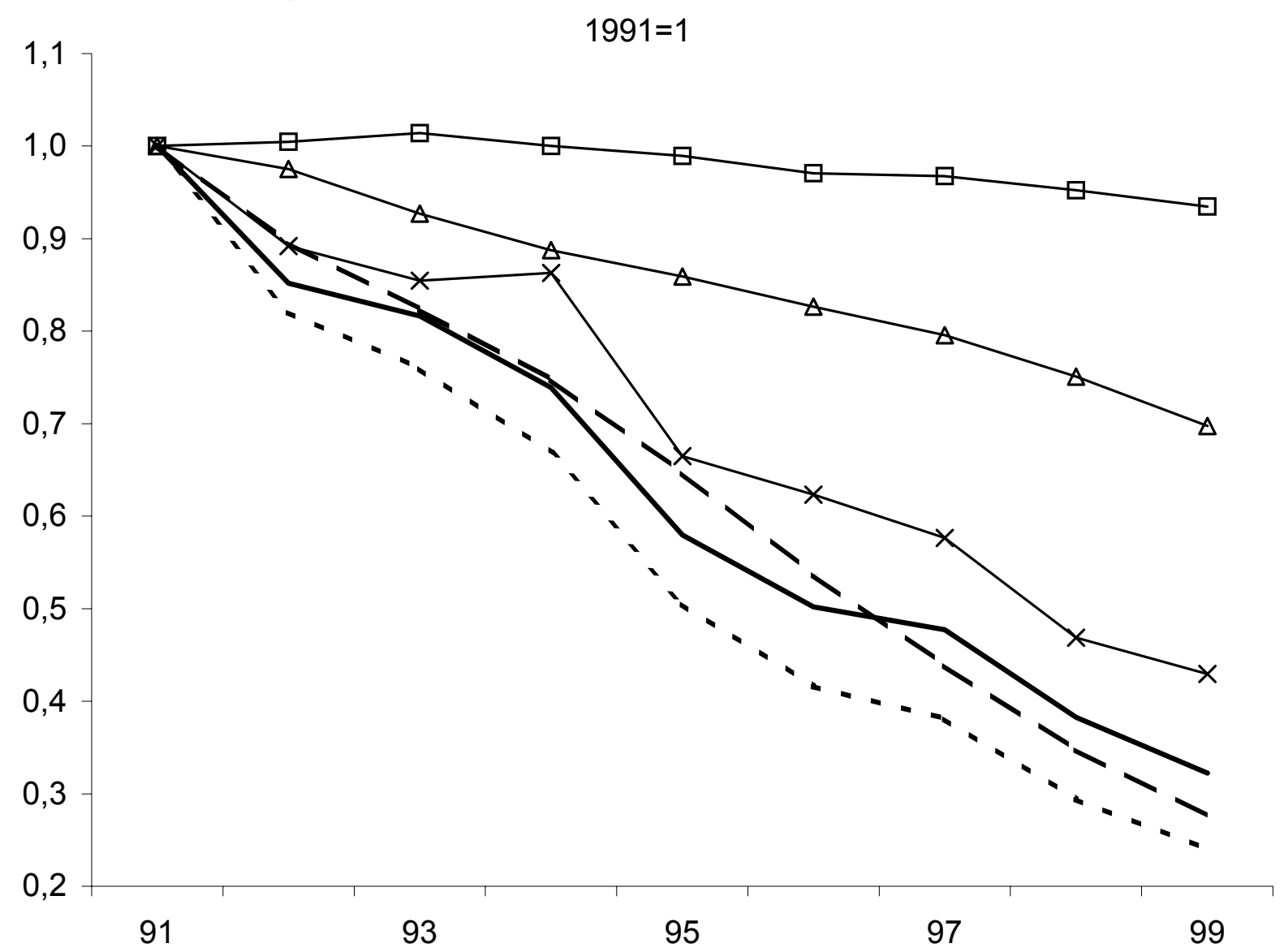

- - - U.S. deflator for OCAM investment, converted into DM using current DM/US\$ exchange rate

$\longrightarrow$ French deflator for OCM investment, converted into DM using current DM/FF exchange rate

U.S. deflator for OCAM investment plus photocopy and related equipment, converted into DM using current DM/US\$ exchange rate

- -U.S deflator for OCAM investment plus photocopy and related equipment, converted into DM using PPP between DM and US\$

$\triangle$ German OCM industry producer price index (DM)

$\square-$ German deflator for OCM investment (DM)

Notes: see Figure 1.

Sources: see Figure 1. 
Figure 3: OCM capital stock (for 35 sectors), 1978-1994,

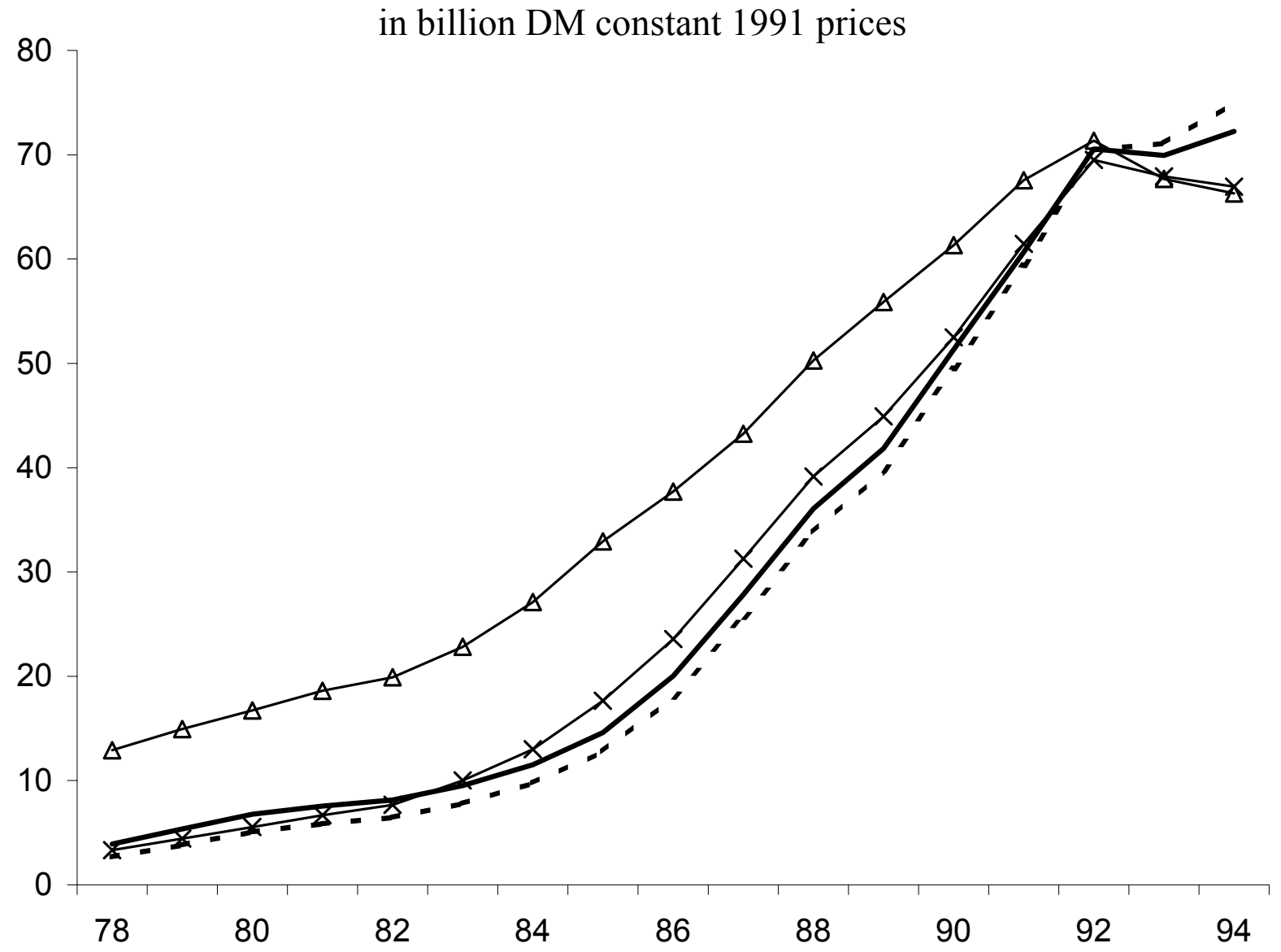

- - - OCM capital stock 1: investment is deflated by the U.S. deflator for OCAM investment, converted into DM using current DM/US\$ exchange rate

$\rightarrow$ OCM capital stock 2: investment is deflated by the French deflator for OCM investment, converted into DM using current DM/FF exchange rate

- OCM capital stock 3: investment is deflated by the U.S. deflator for OCAM investment plus photocopy and related equipment, converted into DM using current DM/US\$ exchange rate

$\triangle$ OCM capital stock 4: investment is deflated by the German OCM industry producer price index

Notes: OCM capital stocks are estimated using the perpetual inventory method. Real investments were computed by dividing nominal investments by the price indices described above. The depreciation rate is 0.2729 over the period 19701977 and 0.3119 over the period 1978-1994. 


\section{IZA Discussion Papers}

\begin{tabular}{|c|c|c|c|c|}
\hline No. & Author(s) & Title & Area & Date \\
\hline 859 & R. Fahr & $\begin{array}{l}\text { Loafing or Learning? The Demand for Informal } \\
\text { Education }\end{array}$ & 5 & $08 / 03$ \\
\hline 860 & $\begin{array}{l}\text { J. Bonke } \\
\text { N. Datta Gupta } \\
\text { N. Smith }\end{array}$ & $\begin{array}{l}\text { Timing and Flexibility of Housework and Men } \\
\text { and Women's Wages }\end{array}$ & 5 & $08 / 03$ \\
\hline 861 & $\begin{array}{l}\text { Y. L'Horty } \\
\text { C. Rault }\end{array}$ & $\begin{array}{l}\text { Inflation, Minimum Wage and Other Wages: An } \\
\text { Econometric Study on French Macroeconomic } \\
\text { Data }\end{array}$ & 1 & $08 / 03$ \\
\hline 862 & $\begin{array}{l}\text { J. T. Addison } \\
\text { C. R. Belfield }\end{array}$ & Union Voice & 3 & $08 / 03$ \\
\hline 863 & C. U. Chiswick & $\begin{array}{l}\text { Immigrant Religious Adjustment: An Economic } \\
\text { Approach to Jewish Migrations }\end{array}$ & 1 & $08 / 03$ \\
\hline 864 & $\begin{array}{l}\text { D. Cobb-Clark } \\
\text { C. Ryan } \\
\text { R. Breunig }\end{array}$ & $\begin{array}{l}\text { A Couples-Based Approach to the Problem of } \\
\text { Workless Families }\end{array}$ & 6 & $08 / 03$ \\
\hline 865 & S. W. Polachek & $\begin{array}{l}\text { Mincer's Overtaking Point and the Lifecycle } \\
\text { Earnings Distribution }\end{array}$ & 5 & $08 / 03$ \\
\hline 866 & A. Constant & $\begin{array}{l}\text { Immigrant Adjustment in France and Impacts on } \\
\text { the Natives }\end{array}$ & 1 & $08 / 03$ \\
\hline 867 & $\begin{array}{l}\text { T. J. Dohmen } \\
\text { B. Kriechel } \\
\text { G. A. Pfann }\end{array}$ & $\begin{array}{l}\text { Monkey Bars and Ladders: The Importance of } \\
\text { Lateral and Vertical Job Mobility in Internal } \\
\text { Labor Market Careers }\end{array}$ & 1 & $08 / 03$ \\
\hline 868 & $\begin{array}{l}\text { P. Brañas Garza } \\
\text { S. Neuman }\end{array}$ & $\begin{array}{l}\text { Analyzing Religiosity Within an Economic } \\
\text { Framework: The Case of Spanish Catholics }\end{array}$ & 5 & $08 / 03$ \\
\hline 869 & $\begin{array}{l}\text { A. B. Krueger } \\
\text { A. Mas }\end{array}$ & $\begin{array}{l}\text { Strikes, Scabs and Tread Separations: Labor } \\
\text { Strife and the Production of Defective } \\
\text { Bridgestone/Firestone Tires }\end{array}$ & 3 & $09 / 03$ \\
\hline 870 & $\begin{array}{l}\text { S. Klasen } \\
\text { A. Launov }\end{array}$ & $\begin{array}{l}\text { Analysis of the Determinants of Fertility Decline } \\
\text { in the Czech Republic }\end{array}$ & 4 & $09 / 03$ \\
\hline 871 & $\begin{array}{l}\text { Y. L'Horty } \\
\text { C. Rault }\end{array}$ & $\begin{array}{l}\text { The Impact of Growth, Labour Cost and Working } \\
\text { Time on Employment: Lessons from the French } \\
\text { Experience }\end{array}$ & 5 & $09 / 03$ \\
\hline 872 & $\begin{array}{l}\text { J. R. Munch } \\
\text { M. Rosholm } \\
\text { M. Svarer }\end{array}$ & Are Home Owners Really More Unemployed? & 1 & $09 / 03$ \\
\hline 873 & $\begin{array}{l}\text { M. Falk } \\
\text { B. M. Koebel }\end{array}$ & $\begin{array}{l}\text { The Impact of Office Machinery and Computer } \\
\text { Capital on the Demand for Heterogeneous } \\
\text { Labour }\end{array}$ & 5 & $09 / 03$ \\
\hline
\end{tabular}

An updated list of IZA Discussion Papers is available on the center's homepage www.iza.org. 